\title{
Editorial
}

\section{The human carotid body}

All students of thoracic disease should be interested in the complex arrangement of blood vessels, nerves, and gland-like tissue within the carotid bifurcation which comprises the carotid body and sinus. There would appear to be a case for immediately declaring these structures to be honorary thoracic organs for, while they are situated in the neck, they appear to be intimately concerned with monitoring vital functions of the heart and lungs such as the maintenance of systemic blood pressure and oxygenation of the blood.

It may be that some are not very clear about the distinction between carotid sinus and carotid body. The sinus is an ill-defined dilatation at the origin of the internal carotid artery in which there is a definite abrupt thinning of the media, which is richly supplied by nerve fibrils. The sinus is concerned with baroreception and physiologists are able to demonstrate in laboratory animals such as the rat how easily and rapidly this thin-walled segment distends and reacts to fluctuations in intravascular pressure. In man, however, this dilated, thin-walled sac, like all aneurysms, proves to be very susceptible to the development of atherosclerosis, ${ }^{1}$ and such progressive fibrosis with age diminishes the extensibility of the sinus and makes it a very stiff baroreceptor indeed. ${ }^{2}$

The carotid body is an ovoid nodule of fawnbrown tissue lying in the loose connective tissue of the carotid bifurcation. It is supplied by one or more glomic arteries, which arise from the common or external carotid arteries ${ }^{34}$; and these give rise to a complex mass of small glomic arteries, which have a highly elastic structure, ${ }^{5}$ and capillaries. Half a century ago de Castro produced neuroanatomical evidence of a profuse afferent nerve supply from the glossopharyngeal nerve for this vascular complex. ${ }^{67}$ His detailed histological studies led him to a novel and intuitive interpretation of the role of this mass of nerves and glomus cells around the vascular plexus-namely, that of a chemoreceptor. His interpretation stimulated a series of experiments from distinguished physiologists, who were able to confirm the responsiveness of the carotid body to hypoxaemia and hypercarbia. ${ }^{8-11}$ Physiologists are still, however, unable to agree about how the carotid

Address for reprint requests: Professor $D$ Heath, University Department of Pathology, Liverpool L69 3BX. body works and no one has been able to identify the essential transducer which is sensitive to a diminished partial pressure of oxygen in the plasma. There is at present no evidence of an endocrine role for the carotid body. The glomus cells have the characteristic structural features of an APUD cell capable of forming a peptide hormone; but no one has yet been able to prove the existence of or ascribe a function to this hypothetical hormone "glomin." 12

The elegant studies of the physiologists lit no spark among the pathologists. They largely ignored the carotid body, confining their interest to the histopathological features of its tumour, the chemodectoma, which are so characteristic that they make very suitable subject matter for such exercises as the final practical examination of the Royal College of Pathologists. Few morbid anatomists ever examine the carotid bodies at necropsy, even in cases of heart and lung disease-probably thinking, quite wrongly, that the demonstration and examination of these organs require a time-consuming dissection and a meticulous study of serial sections. In fact, all that is required is a pair of scissors, about five minutes, and (most important) the will power to examine these tissues. The authors of undergraduate texts of pathology have also shunned the carotid bodies, so the ignorance is passed on to the next generation. The result of this neglect is a peculiar imbalance in our knowledge of these organs. While physiologists have carried out sophisticated and elegant studies on the carotid bodies of animals, pathologists have failed to learn even the most basic reactions of the organs in generalised disease through not examining them routinely at necrospy like other viscera.

In view of all this, it is not surprising that the first report of structural changes in the carotid bodies in response to altered physiological conditions in the body came not from a hospital or university department of pathology but from the more exotic setting of field work in the Peruvian Andes. In 1969 Arias-Stella reported that the carotid bodies of Quechua Indians born and living at high altitude were larger than those of mestizos on the coast. ${ }^{13}$ Subsequently, during one of our expeditions to the Altiplano we were able to show that the carotid bodies of domestic animals living at high altitude were larger than those of the same species living on 
the coast. ${ }^{14}$ The implication was that the carotid bodies were undergoing hyperplasia in response to a sustained stimulus of hypoxaemia secondary to chronic hypobaric hypoxia. It was not altogether unexpected therefore when the carotid bodies were found to show a similar enlargement in patients with chronic bronchitis and emphysema who had chronic hypoxaemia - the "blue bloaters." 15 Since right ventricular hypertrophy occurs in such patients with hypoxic pulmonary vasoconstriction a relation between the weight of the right ventricule and the carotid body might have been expected and was in fact found. ${ }^{15}$

At the same time the carotid bodies of highaltitude animals showed ultrastructural changes probably related to the stimulus of chronic hypoxia. These changes occurred in the chief cells, usually considered to be concerned with the chemoreceptor response, and they affected the neurosecretory vesicles. These are organelles consisting of a central osmiophilic core surrounded by a thin, clear halo and they probably contain biogenic amines and peptides concerned with the chemoreceptor response or even with an endocrine function. In hypoxaemia the core became smaller, paler, and eccentric, so that the vesicles were converted into microvacuoles. ${ }^{16} 17$ Such electronmicroscopic changes are clearly characteristic of hypoxia, but the precise significance of each element of the process remains obscure.

There appears to be a certain logic in most of this and we can relate most of the structural changes to the idea that the carotid body is first and foremost a chemoreceptor. Nevertheless, some observations do not seem to fit easily into this tidy scheme. A decade ago we became aware that there was a relation between the weight of the left cardiac ventricle and of the carotid bodies. ${ }^{15}$ More recent histological studies of carotid bodies obtained from a series of necropsies at the Royal Liverpool Hospital show that carotid body hyperplasia occurs in systemic hypertension as well as in chronic hypoxaemia complicating pulmonary emphysema..$^{18}$ This observation on human tissue has been confirmed by the finding of enlargement of the carotid bodies in spontaneously hypertensive rats of the Okamoto strain $^{20}$ (also unpublished observations).

Probably most physiologists would suspect that the rounded chief (type I) cell was the transducer monitoring the partial pressure of oxygen in the plasma and so it might be confidently anticipated that carotid body hyperplasia, certainly in chronic hypoxaemia and possibly in systemic hypertension, might be due to proliferation of chief cells. This expectation is not realised in man, and in fact in both conditions the enlargement is due to hyperplasia of elongated cells at the periphery of clusters of chief cells compressing them-and therefore perhaps responsible for diminution of hypoxic drive in such hypoxic patients. The elongated cells are difficult to identify with certainty by light microscopy ${ }^{18}$ but ultrastructural studies (unpublished observations) show them to be a mixture of sustentacular (type II) cells and Schwann cells, with plentiful nerve axons enfolded by the Schwann cells much in evidence. It is unexpected and interesting that both systemic hypertension and chronic hypoxaemia induce the identical form of histopathology and that the tissues most concerned are sustentacular and Schwann cells with many associated nerve axons. Perhaps the axon itself is the missing transducer.

It is not surprising that the carotid body is so sensitive to the level of intravascular pressure since it lies adjacent to the carotid sinus, with its baroreceptor function and rich nerve supply intermingling with that of the carotid body. The nature of the glomic arteries supplying the carotid bodies, however, suggests that they are themselves directly sensitive to fluctuation in blood pressure. Whenever arteries approach glomic tissue they lose the typical appearance of a muscular systemic artery to acquire the characteristic of an elastic vessel despite their diminutive diameter. This combination of a highly elastic wall with a rich nerve supply is reminiscent of the wall of the carotid sinus and suggests that the vessel directly subserves a baroreceptor function. This richly elastic appearance is seen in the main glomic arteries, ${ }^{34}$ in the branches of glomic arteries deep in the substance of the carotid bodies, ${ }^{5}$ in arteries supplying intertruncal glomera in the mediastinum, ${ }^{21}$ and in the so-called "glomus pulmonale." 22 These small elastic interlobular arteries running through the carotid body give rise to muscular intralobular arterioles, which appear able to control the flow of blood into the glomic capillaries. ${ }^{5}$ It is a matter of conjecture whether reflexes initiated by stimulation of the walls of the elastic arteries lead to constriction of these intralobular arterioles.

Prolonged stimulation of the human carotid body by systemic hypertension or severe hypoxaemia appears to induce a second, distinct type of histopathology. ${ }^{23}$ This is characterised by focal proliferation of dark or of "pyknotic" variants of chief cells. ${ }^{23}$ In the former the nucleus is smaller and contains more heterochromatin than in the usual light type of chief cell and its cytoplasm is condensed and darker. In the "pyknotic" variant the nucleus is much smaller and compact as in necrotic tissue, but the cell has this appearance while in fact undergoing proliferation.

Conceivably this late focal proliferation of variants of chief cells may represent the early stages of development of chemodectoma, a tumour known to 
be commoner at high altitude. ${ }^{17}$ As early as 1973 Saldaña and his colleagues ${ }^{24}$ reported that all but two of 25 Peruvian adults with chemodectomas of the head and neck had been born and lived at high altitudes up to $4350 \mathrm{~m}$ above sea level, whereas only $38 \%$ of the Peruvian population of 13.5 million live at or above an altitude of $3000 \mathrm{~m}$. In their series they found that all the carotid body tumours were benign, while one patient had a malignant glomus jugulare tumour. Females predominated over males by about six to one and left-sided were three times as common as right-sided tumours. The tumour cells were arranged in clusters and comprised chief cells with the dark variant predominating. Interestingly, two of the reported patients from the Andes with chemodectomas died from metastasising carcinoma of the thyroid. ${ }^{2425}$ This association of chemodectoma with thyroid carcinoma was noted in two patients in Mexico City at an altitude of $2380 \mathrm{~m}^{26}$ The same sequence of carotid body hyperplasia and chemodectoma formation occurs in cattle at high altitude. ${ }^{27}$

The carotid body of man appears to differ from that of animals both in its structure and in its reaction to disease. In human glomic tissue both the dark and the pyknotic variants of chief cells are welldefined entities ${ }^{18}$ and, as we have seen, may show focal proliferation with prolonged exposure to systemic hypertension and chronic hypoxaemia. ${ }^{23}$ In contrast, in rats dark and pyknotic variants are difficult to distinguish and are even regarded by some workers as artefacts due to tissue damage and inadequate fixation. ${ }^{28}$ The striking hyperplasia of elongated sustentacular and Schwann cells that occurs in the human carotid body has not been reported in the glomic tissue of spontaneously hypertensive rats ${ }^{20}$ or of rats exposed to hypobaric hypoxia. ${ }^{29}{ }^{30}$ Such considerations cast doubt on the suitability of the carotid body of the rat as an animal model for the human organ. Its reactions in disease appear to be different from those seen in man.

All in all, there would appear to be a growing case for taking more account of the carotid bodies and for not dismissing them as of only passing and peripheral interest to those concerned in the study and treatment of lung disease. Pathologists might even be encouraged to start examining the carotid bodies in cases of cardiopulmonary disease coming to necropsy.

DONALD HEATH

Department of Pathology University of Liverpool

\section{References}

' Heath D, Smith P, Harris P, Winson M. The atherosclerotic human carotid sinus. J Pathol 1973;110:49-
58.

${ }^{2}$ Winson M, Heath D, Smith P. Extensibility of the human carotid sinus. Cardiovasc Res 1973;8:58-64.

${ }^{3}$ Heath D, Edwards C. The glomic arteries. Cardiovasc Res 1971;5:303-12.

4 Jago R, Heath D, Smith P. Structure of the glomic arteries. J Pathol 1982;138:205-18.

${ }^{5}$ Heath D, Jago R, Smith P. The vasculature of the carotid body. Cardiovasc Res 1983;17:33-42

${ }^{6}$ de Castro F. Sur la structure et l'innervation de la glande intercarotidienne (glomus caroticum) de l'homme et des mammifères, et sur un nouveau système d'innervation autonome du nerf glossopharyngien: études anatomique et expérimentales. Trab Lab Rech Biol Univ Madrid 1926;24:365-432.

${ }^{7}$ de Castro F. Sur la structure et l'innervation de sinus carotidien de l'homme et des mammifères: nouveaux faits sur l'innervation et la fonction du glomus caroticum: études anatomiques et physiologiques. Trab Lab Rech Biol Univ Madrid 1928;25:330-80.

${ }^{8}$ Heymans C, Bouckaert JJ, Dautrebande L. Sinus carotidien et réflexes respiratoires. II-influences respiratoires réflexes de l'acidose, de l'alcalose, de l'anhydride carbonique, de l'ion hydrogene et de l'anoxémie: sinus carotidiens et échanges respiratoires dans les poumons et au dela des poumons. Arch Int Pharmacodyn Ther 1930;39:400-8.

${ }^{9}$ Comroe JH jun, Schmidt CF. The part played by reflexes from the carotid body in the chemical regulation of respiration in the dog. Am J Physiol 1938;121:75-97.

${ }^{10}$ Joels N, Neil E. The excitation mechanism of the carotid body. Br Med Bull 1963;19:21-4.

${ }^{11}$ Grimley PM, Glenner GG. Ultrastructure of the human carotid body. A perspective on the mode of chemoreception. Circulation 1968;37:648-65.

${ }^{12}$ Pearse AGE. The cytochemistry and ultrastructure of polypeptide hormone-producing cells of the APUD series and the embryologic, physiologic and pathologic implications of the concept. J Histochem Cytochem 1969;17:303-13.

${ }^{13}$ Arias-Stella J. Human carotid body at high altitudes. Am J Pathol 1969;55:82a (abstract).

${ }^{14}$ Edwards C, Heath D, Harris P, Castillo Y, Krüger H, Arias-Stella $J$. The carotid body in animals at high altitude. J Pathol 1971;104:231-8.

${ }^{15}$ Edwards C, Heath D, Harris P. The carotid body in emphysema and left ventricular hypertrophy. J Pathol 1971;104:1-13.

${ }^{16}$ Edwards C, Heath D, Harris P. Ultrastructure of the carotid body in high-altitude guinea-pigs. J Pathol 1972;107:131-6.

${ }^{17}$ Heath D, Williams DR. Man at high altitude. 2nd ed. Edinburgh: Churchill Livingstone, 1981.

${ }^{18}$ Smith P, Jago R, Heath D. Anatomical variation and quantitative histology of the normal and enlarged carotid body. J Pathol 1982;137:287-304.

${ }^{19}$ Heath D, Smith P, Jago R. Hyperplasia of the carotid body. J Pathol 1982;138:115-27.

${ }^{20}$ Honig A, Schmidt M. Kidney function during carotid chemoreceptor stimulation: influence of unilateral renal nerve section. In: Schrier RW, Ponec J, eds. Hormonal regulation of sodium excretion. Amsterdam: Elsevier North-Holland Biomedical Press, 1980:93-8.

${ }^{21}$ Edwards C, Heath D. Site and blood supply of the intertruncal glomera. Cardiovasc Res 1970;4:502-8. 
${ }^{22}$ Edwards C, Heath D. Microanatomy of glomic tissue of the pulmonary trunk. Thorax 1969;24:209-17.

${ }^{23}$ Heath D, Smith P, Jago R. Dark cell proliferation in carotid body hyperplasia. J Pathol (in press).

${ }^{24}$ Saldafia MJ, Salem JE, Travezan R. High altitude hypoxia and chemodectomas. Hum Pathol 1973;4: 251-63.

${ }^{25}$ Saldana MJ, Salem JE. High altitude hypoxia and chemodectomas. Am J Pathol 1970;59:91-2a (abstract).

${ }^{26}$ Albores-Saavedra J, Duran ME. Association of thyroid carcinoma and chemodectoma. Am J Surg 1968;116:887-90.

${ }^{27}$ Arias-Stella J, Bustos F. Chronic hypoxia and chemodectomas in bovines at high altitudes. Arch Pathol Lab Med 1976;100:636-9.

${ }^{28}$ McDonald DM. Peripheral chemoreceptors: structurefunction relationships of the carotid body. In: Hornbein TF, ed. Regulation of breathing. Part 1. New York: Marcel Dekker 1981:105.

${ }^{29}$ Laidler P, Kay JM. Ultrastructure of carotid body in rats living at a simulated altitude of $\mathbf{4 3 0 0}$ metres.J Pathol 1978;124:27-33.

${ }^{30}$ Laidler P, Kay JM. A quantitative study of some ultrastructural features of the type $I$ cells in the carotid bodies of rats living at a simulated altitude of 4300 metres. J Neurocytol 1978;7:183-92. 